\title{
Development and chemical characterization of flour obtained from the external mesocarp of "pequizeiro" fruit
}

\author{
Desenvolvimento e caracterização química de farinha obtida do mesocarpo externo do fruto do pequizeiro
}

\author{
Manoel Soares SOARES JÚNIOR ${ }^{2 *}$, Priscila Zaczuk BASSINELLOํ, ${ }^{1}$ Márcio CALIARI ${ }^{2}$, \\ Renata Cunha dos REIS ${ }^{2}$, Diracy Betânia Cavalcante Lemos LACERDA ${ }^{2}$, Selma Nakamoto KOAKUZU ${ }^{1}$
}

\begin{abstract}
The objective of this work was to develop a recommendation for the chemical peeling of pequi fruit and characterize the flour obtained from the external mesocarp of "Pequizeiro", pequi tree (Caryocar brasiliense Camb.). The technology applied to obtain the external mesocarp pequi flour included the epicarp removal with $\mathrm{NaOH}$ solution. The Response Surface Method was used to optimize the chemical peeling process by applying the Central Composite Rotatable Design, with eleven trials including three replicates at the central point, varying the $\mathrm{NaOH}$ aqueous solution concentration and fruit immersion time. The mass loss was evaluated through the analysis of variance and using bi and three dimensional graphs. The chemical characteristics of the external mesocarp pequi flour evaluated were: moisture content, ashes, proteins, lipids, total carbohydrates, dietary fiber, and some minerals. The best combination for an efficient removal of the fruit peel with the lowest mass loss was reached with 7.05 minutes of immersion in a $5.08 \mathrm{~g} . \mathrm{L}^{-1} \mathrm{NaOH}$ aqueous solution. This study indicated that the external mesocarp pequi flour is a food source rich in dietary fiber, carbohydrates, ashes, magnesium, calcium, manganese, and copper, but it is poor in lipids, zinc, and iron.
\end{abstract}

Keywords: development of products; utilization of residues; Caryocar brasiliense Camb.; dietary fiber.

\section{Resumo}

O objetivo deste trabalho foi desenvolver uma recomendação para o descascamento químico do pequi e caracterizar a farinha de casca de frutos de pequizeiro (Caryocar brasiliense Camb.). A tecnologia desenvolvida para a obtenção da Farinha de Casca de Pequi (FCP) incluiu a remoção do epicarpo do fruto em solução de $\mathrm{NaOH}$. Empregou-se a metodologia de superfície de resposta para otimização do descascamento químico utilizando-se o modelo central composto rotacional com onze ensaios, incluindo três repetições no ponto central, variando-se a concentração de $\mathrm{NaOH}$ e o tempo de imersão do fruto na solução e avaliando-se a perda de massa por meio de análise de variância e gráficos bi e tridimensionais. Para a FCP, determinaram-se umidade, cinzas, proteínas, lipídios, carboidratos totais, fibra alimentar e alguns minerais A combinação mais adequada para a eficiente remoção do epicarpo do pequi e menor perda de massa foi de 7,05 minutos de imersão em solução com concentração de $\mathrm{NaOH}$ de 5,08 g. $\mathrm{L}^{-1}$. Verificou-se que a FCP é um alimento rico em fibra alimentar, carboidratos, cinzas, magnésio, cálcio, manganês e cobre, mas pobre em lipídios, zinco e ferro.

Palavras-chave: desenvolvimento de produto; aproveitamento de resíduos; Caryocar brasiliense Camb.; fibra alimentar.

\section{Introduction}

International interest for native fruits from Brazil has been continuously increasing and the Cerrado biome is one of the largest producers of those fruits (FERREIRA, 1980; SILVA et al., 1994, SILVA; CHAVES; NAVES, 2001; ROESLER et al., 2007). The exploration of this biome has been extractive and even predatory; though, it is important to assess the potential and possibilities of a more rational use of fruits native to this vegetation (KLINK; MACHADO, 2005).

"Pequizeiro" (Cariocar brasiliense Camb.) is a typical cerrado tree with a high commercial value. The composition of the fruit is: $76.0 \%$ pericarp and $21.6 \%$ pyrenes, from which $8.5 \%$ is pulp and $2.1 \%$ almond. The pericarp (residue) is formed by the greenish-grey epicarp and the external fleshy-leathery mesocarp. The internal mesocarp (pulp) is fleshy, with light yellow to orange color, enclosing a layer of very thin and hard spines originated on the inner wall of the endocarp. The endocarp lodges the almond (VERA et al., 2005). The highest economic potential of the pequi tree lies in its fruits)- the pyrenes; widely used in the regional cuisine and very much appreciated by the central Brazilian population (VERA et al., 2007). Presently, the pequi pericarp is not included in human food. However, its high content of fibers and other carbohydrates could be used by the agricultural industry instead of being disposed off as residue.

The addition of fibers in food is an alternative to compensate diet deficiencies. The increase in demand for dietary fibers has also demanded economic incentives to develop and market products with higher fiber content. Food industry has been

Recebido para publicação em 12/9/2008

Aceito para publicação em 7/7/2009 (003268)

${ }^{1}$ Centro Nacional de Pesquisa em Arroz e Feijão, Embrapa Arroz e Feijão, CEP 75375-000, Santo Antônio de Goiás - GO, Brasil

2 Escola de Agronomia e Engenharia de Alimentos, Universidade Federal de Goiás - UFG, CEP 74001-970, Goiânia - GO, Brasil, E-mail: manoel@agro.ufg.br

${ }^{*}$ A quem a correspondência deve ser enviada 
isolating dietary fibers from many sources to add in their products (WALTER et al., 1985; ALESON-CABONELL et al., 2004; EASTWOOD, 2005; GARCÍA et al., 2007). Dietary fibers are naturally found in horticultural products, fruits, whole grain, legumes, and seeds (INSTITUTE OF MEDICINE, 2001), and they are widely recommended due to their properties related to improving health. Nowadays, they are classified as functional food due to their beneficial effects on human body, such as lowering blood cholesterol, cancer prevention, increase in intestinal function, intervention in the metabolism of lipids, and carbohydrates, and in the physiology of the gastro intestinal tract (DE VRIES, 2004; PHILLIPS et al., 2008).

The "Pequi" fruits present a large variation of size, shape, and weight (VERA et al., 2005, 2007). The lack of fruit uniformity make the use of industrial equipment usually applied for vegetable processing, such as abrasive machinery, more difficult. So, the "pequi" epicarp (rich in tannins) removal can be done manually or chemically using a hot sodium hydroxide solution.

Tannins are secondary plant polyphenols with great diversity. They have a high affinity for proteins and polysaccharides. Tannins produced by different plants, by different parts of the plants, or in particular seasons can have different physical and chemical properties (CHUNG et al., 1998; SANTOS BUEGA; SCALBERT, 2000; WAGHORN; McNABB, 2003).

The peeling of certain fruits and vegetables is done manually; sometimes in combination with other preliminary practices. This process requires specific procedures, skilled labor, and special tools besides becoming expensive and sometimes subject to waste when compared to chemical peeling (CRUESS, 1973). In the chemical peeling of vegetables, the yield varies according to the treatment, which is inversely proportional to the increase of concentration, temperature, and time of immersion in the basic solution indicating that higher yields can be reached with less drastic conditions of treatment (GARROTE et al., 1993). In the chemical peeling process, after the removal of the epicarp, the external mesocarp may be used to elaborate a flour rich in dietary fiber with potential to replace portions of wheat flour in bakery. Industrial processing of pequi could become an option for the sustainable development of the cerrado region.

The objective of this work was to develop a recommendation for the chemical peeling of pequi fruit and characterize the flour obtained from the external mesocarp of "Pequizeiro" fruit.

\section{Materials and methods}

Fruits of the pequi tree (Caryocar brasiliense Camb.) from São Miguel do Araguaia - GO, Brazil, harvested in 2006 were purchased at the Fruit and Vegetable Central Market (Ceasa GO) in Goiânia - GO and taken to the Department of Food Science and Technology at the School of Agronomy and Food Engineering of the Federal University of Goiás, where they were washed and the fruits without mechanical damage were selected. The fruits were washed and selected considering the absence of visual injuries and infections; their size uniformity, color, and firmness were also taken into account.

Fifty-five fruits were chosen, cleaned with neutral detergent, washed with tap water, and dried with paper towel. Afterwards, the following measurements were made: size of smaller (1) and larger (2) diameters, fruit mass and height, and shell mass and mass of pyrenes + fruitlets. The measurements were performed using a paquimeter and an analytical scale.

The first step in the development of the flour was the removal of the epicarp from the fruit. That procedure was performed using a chemical treatment with sodium hydroxide $(\mathrm{NaOH})$ aqueous solution. This product was used because that layer is thick, hard, and very difficult to remove by hand. To study the chemical peeling process, evaluated through mass loss measurements $(\mathrm{Z})$, the surface response method and the Central Composite Rotatable Design, with eleven experiments including three replicates at the central point, were used varying the concentration of $\mathrm{NaOH}$ in the aqueous solution $(\mathrm{X})$ and the time of immersion in the solution $(\mathrm{Y})$. The variation intervals were defined from preliminary tests (Table 1).

Five fruits per experiment were individually numbered and weighted. A $1000 \mathrm{~mL}$ becker and a hot plate were used to heat up $500 \mathrm{~mL}$ of solution to boiling point $\left(95^{\circ} \mathrm{C}\right)$. Each fruit was individually immersed in the solutions with concentration and time previously determined in the experimental design. After the fruits were immersed, they were washed with tap water to remove the lixiviated epicarp, and the external mesocarp was collected. Finally, the external mesocarp was dried with paper towel and weighed to determine the percentage of mass loss, calculated through Equation 1.

Percentage of mass loss $(\mathrm{Z})=$

$=[($ Initial mass $)-($ End mass $)] \times(\text { Initial mass })^{-1} \times 100$

To evaluate the data using the analysis of variance (STATISTICA, 1995), a mathematical transformation model was used. A valid application of significance tests in the analysis of variance requires that experimental errors be independently and normally distributed with a common variance. The angular transformation is applicable to binomial data expressed as decimal fractions or percentages (STEEL; TORRIE, 1980). The results of mass loss percentage $(Z)$ were submitted to that model (results in value W) through Equation 2 (STEEL; TORRIE, 1980).

$W=\arcsin \sqrt{Z / 100}$

Table 1. Experimental design (actual and code values of the independent variables).

\begin{tabular}{lcccccc}
\hline Trial & \multicolumn{2}{c}{ NaOH concentration } & & \multicolumn{2}{c}{ Time of immersion } \\
\cline { 2 - 3 } \cline { 5 - 6 } & Code values & $\begin{array}{c}\text { Actual values } \\
\left(\mathrm{g} . \mathrm{L}^{-1}\right)\end{array}$ & & & Code values & $\begin{array}{c}\text { Actual values } \\
\left(\mathrm{g} . \mathrm{L}^{-1}\right)\end{array}$ \\
\hline 1 & -1 & 3.41 & & -1 & 2.45 \\
2 & -1 & 3.41 & & +1 & 7.05 \\
3 & 0 & 8.25 & & -1.41 & 1.50 \\
4 & 0 & 8.25 & & +1.41 & 8.00 \\
5 & 0 & 8.25 & & 0 & 4.75 \\
6 & +1 & 13.04 & & -1 & 2.45 \\
7 & +1 & 13.04 & & +1 & 7.05 \\
8 & 0 & 8.25 & & 0 & 4.75 \\
9 & 0 & 8.25 & & 0 & 4.75 \\
10 & -1.41 & 1.50 & & 0 & 4.75 \\
11 & +1.41 & 15.0 & & 0 & 4.75 \\
\hline
\end{tabular}


Bi-dimensional and three-dimensional graphs were built for a better visualization of the effect of the independent variables on the converted mass loss percentage using applicative Statistica (1995). Through visual comparison of the efficiency of the peeling (removal and no removal) of the pericarp in each experiment and through less transformed mass loss on the graphs, it was possible to obtain the ideal condition $(\mathrm{NaOH}$ concentration and time of immersion) to adequately remove the epicarp using chemical solution.

To process the external mesocarp pequi flour, the chemical peeling was performed with larger batches. One $\mathrm{kg}$ of fruit was immersed in a $20 \mathrm{~L}$ stainless steel pan containing $10 \mathrm{~L}$ of $\mathrm{NaOH}$ aqueous solution with concentration and immersion time determined in the peeling experiment as a function of fruit mass and peeling efficiency. After the fruits were washed, the corroded peel was removed by hand and the fruits were immediately immersed in a diluted solution (3.0\%) of acetic acid for three minutes to neutralize residual alkalinity. Next, the fruits were cut along their diameter with a stainless steel knife thus separating the two halves of the external mesocarp and the pyrenes. These halves were blanched in boiling water for six minutes and dried in an oven with forced air for 16 hours at $60{ }^{\circ} \mathrm{C}$. The dehydrated product was then cooled at room temperature and ground in a blades mill. Finally, the flour was stored in polyethylene bags ( $0.01 \mathrm{~mm}$ thickness) inside closed cardboard boxes at room temperature and without relative air humidity control until the analyses were performed.

The chemical analyses were performed in triplicate at the Embrapa Rice and Beans Food Technology Laboratory, in Santo Antonio de Goias - GO. The percent composition was determined according to procedures described by A.O.A.C. International (ASSOCIATION..., 1997) as follows: moisture content in an oven at $105^{\circ} \mathrm{C}$ (No. 925.10); nitrogen by Kjeldahl method, converted to whole protein by multiplying by conversion factor 6.25 (No. 960.52); ashes by incineration in furnace at $550{ }^{\circ} \mathrm{C}$ (No. 923.03); lipids by direct extraction in Soxhlet (No. 920.39C) and carbohydrates calculated by difference, subtracting from 100 the values found for proteins, lipids, total dietary fiber, and mineral residue. The total dietary fiber was determined by the enzyme-gravimetric method according to the A.O.A.C International (ASSOCIATION..., 1997) official method No. 985.29. Calcium, magnesium, copper, manganese, iron, and zinc contents were analytically quantified following the A.O.A.C. International (ASSOCIATION..., 1997) method No. 965.9 modified. Dried and ground samples were oxidized with a solution of nitric and perchloric acids and then digested in a block digester with controlled temperature and diluted in deionized water. Atomic absorption spectrophotometry was conducted (PERKIN ELMER, 306). Lanthanum was added to calcium and magnesium extracts to avoid possible interference of phosphates and aluminum while the other mineral observations were made directly on the extracts.

\section{Results and discussion}

Means, standard deviation, and coefficient of variation of the physical parameters from the data obtained from pequizeiro fruits are shown on Table 2. The fruit mass varied from 81.59 to
Table 2. Means, Standard deviation and coefficient of variation of mass, diameters (1) and (2), height of whole fruit, and shell mass and pyrene + fruitlets mass of pequizeiro (Caryocar brasiliense Camb.) fruit from São Miguel do Araguaia - GO, Brasil (2006 harvest).

\begin{tabular}{lc}
\hline \multicolumn{1}{c}{ Dimensions } & $\begin{array}{c}\text { Means } \pm \text { standard deviation } \\
\text { (coefficient of variation) }\end{array}$ \\
\hline Fruit mass $(\mathrm{g})$ & $142.46 \pm 32.33(22.70)$ \\
Diameter $(1)(\mathrm{mm})$ & $66.39 \pm 8.77(13.21)$ \\
Diameter $(2)(\mathrm{mm})$ & $66.87 \pm 9.21(13.87)$ \\
Height $(\mathrm{mm})$ & $68.02 \pm 7.78(11.43)$ \\
Shell mass $(\mathrm{g})$ & $113.74 \pm 31.63(28.03)$ \\
Pyrenes + fruitlets mass $(\mathrm{g})$ & $29.22 \pm 7.33(25.07)$ \\
\hline
\end{tabular}

$198.13 \mathrm{~g}$, with a mean of $142.45 \mathrm{~g}$. These values are within the interval of variation observed by Vera et al. (2007), working in Araguapaz - GO. They reported a variation in mass of the whole fruit from 46.38 to $209.81 \mathrm{~g}$ and an average of $103.50 \mathrm{~g}$. The results obtained in this study show larger average mass values than those obtained by Vera et al. (2007). The fruit smallest diameter (1) varied from 47.56 to $86.87 \mathrm{~mm}$, with an average of $66.39 \mathrm{~mm}$, while these values varied from 43.53 to $88.92 \mathrm{~mm}$ for the greatest diameter (2) with an average of $66.87 \mathrm{~mm}$. Vera et al. (2005), studying "pequis" from different locations in the State of Goiás found diameter sizes from 55.40 to $64.80 \mathrm{~mm}$ for medium and large fruits. These fruits were smaller than the average obtained in this study for fruits from São Miguel do Araguaia region.

Fruit heights were distributed in the interval 49.93 $89.95 \mathrm{~mm}$, with an average of $68.02 \mathrm{~mm}$. Silva et al. (1994) also reported fruit heights from 60.00 to $1400.00 \mathrm{~mm}$ in fruits collected on Brasilia boundaries. These sizes being larger than those observed in this study. Shell (epicarp and external mesocarp) mass data were between 52.51 and $163.68 \mathrm{~g}$ with an average of $113.88 \mathrm{~g}$. Vera et al. (2007) reported shell mass varying from 59.32 to $303.80 \mathrm{~g}$ with an average of $139.36 \mathrm{~g}$ from Mambaí region, also larger than those found in this study. However the same authors found lower shell mass values in fruits from the Araguapaz region - they oscillate between 34.54 and $174.32 \mathrm{~g}$ with an average of $80.49 \mathrm{~g}$. Pyrene mass varied from 13.26 to $52.32 \mathrm{~g}$ with an average of $30.54 \mathrm{~g}$. Comparing the mean values obtained from whole fruits and exocarp mass, it was observed a ratio of approximately 0.79 . Vera et al. (2007) reported that although there was variability in the fruit mass, the ratio between the average shell mass and average mass fruit remained constant in Mambai and Araguapaz regions, around 0.78, slightly below the average obtained for the fruits in this study. When analyzing the results from the literature, various authors also found great variability in fruit dimensions and mass, which makes the mechanical removal of "pequi" epicarp more difficult.

The data obtained for percentage mass loss and converted mass loss during the chemical peeling process as well as the experimental design are on Table 3.

The adjusted model for converted mass loss was significant $(\mathrm{P}=0.03226)$. The coefficients of determination and variation were 92.544 and $10.02 \%$, respectively, and the lack of fit of the model was not significant $(\mathrm{LF}=0.0896)$ and the math model was represented by the Equation 3 suggesting that this model could 
be applied to predict responses since it has all the acceptable parameters of the analysis of variance. Table 4 presents the ANOVA table for the converted mass loss:

\section{$Z=19.733+1.3807 X+5.704 Y$}

The non uniformity (high coefficient of variation and standard deviation) in fruit dimensions could have influenced fruit mass loss during the chemical peeling, which could explain the coefficient of variation values observed in this model (Table 2). Two and three dimensional graphs indicate that the converted mass loss was affected by variations in $\mathrm{NaOH}$ concentration $(\mathrm{X})$ and time of immersion in the solution $(\mathrm{Y})$ during the chemical peeling using the appropriate mathematical model (Figure 1).

In the response surface graphs, it can be noted a loss of converted mass in the range of 10.0 and 30.0, i.e., between 3.02 and $25 \%$ of mass loss. The linear effects of time of immersion and $\mathrm{NaOH}$ solution concentration were significant $(\mathrm{p} \leq 0.05)$, but the quadratic and interaction effects were not significant $(p>0.05)$ indicating that the loss of mass increased linearly with the rise in $\mathrm{NaOH}$ concentration and with time of immersion.

On trials (2) with 3.41 g.. $\mathrm{L}^{-1}$ and 7.05 minutes, (3) with 8.25 g.L. ${ }^{-1}$ and 1.50 minutes, and (10) with 1.50 g.L. ${ }^{-1}$ and 4.75 minutes, the products showed a greenish color after peeling, probably due to the incomplete removal of the epicarp, in

Table 3. Mass loss (\%) and converted mass loss during chemical removal of the epicarp of pequi fruit as a function of the time of immersion (minutes) and $\mathrm{NaOH}$ concentration (g. $\mathrm{L}^{-1}$ ) as well as the experimental design used (actual and code values of the independent variables).

\begin{tabular}{|c|c|c|c|c|c|c|}
\hline \multirow[t]{2}{*}{ Trial } & \multicolumn{2}{|c|}{$\mathrm{NaOH}$ concentration } & \multicolumn{2}{|c|}{ Time of immersion } & \multicolumn{2}{|c|}{ Mass loss } \\
\hline & $\begin{array}{c}\text { Code } \\
\text { values }\end{array}$ & $\begin{array}{c}\text { Actual values } \\
\left(\text { g. } \mathrm{L}^{-1}\right)\end{array}$ & $\begin{array}{c}\text { Code } \\
\text { values }\end{array}$ & $\begin{array}{c}\text { Actual values } \\
\left(\text { g. } \mathrm{L}^{-1}\right)\end{array}$ & (\%) & Transformed \\
\hline 1 & -1 & 3.41 & -1 & 2.45 & 1.90 & 0.79 \\
\hline 2 & -1 & 3.41 & +1 & 7.05 & 6.09 & 1.41 \\
\hline 3 & 0 & 8.25 & -1.41 & 1.50 & 7.31 & 1.54 \\
\hline 4 & 0 & 8.25 & +1.41 & 8.00 & 19.60 & 2.54 \\
\hline 5 & 0 & 8.25 & 0 & 4.75 & 11.28 & 1.93 \\
\hline 6 & +1 & 13.04 & -1 & 2.45 & 17.51 & 2.40 \\
\hline 7 & +1 & 13.04 & +1 & 7.05 & 19.51 & 2.53 \\
\hline 8 & 0 & 8.25 & 0 & 4.75 & 11.41 & 1.94 \\
\hline 9 & 0 & 8.25 & 0 & 4.75 & 12.92 & 2.06 \\
\hline 10 & -1.41 & 1.50 & 0 & 4.75 & 3.89 & 1.13 \\
\hline 11 & +1.41 & 15.0 & 0 & 4.75 & 25.17 & 2.88 \\
\hline
\end{tabular}

Table 4. Regression coefficients of converted mass loss during chemical removal of the epicarp of pequizeiro (Caryocar brasiliense Camb.) fruit as a function of the time of immersion (minutes) and $\mathrm{NaOH}$ concentration (g.L $\left.\mathrm{L}^{-1}\right)$

\begin{tabular}{lcccc}
\hline \multicolumn{1}{c}{ Factor } & $\begin{array}{c}\text { Regression } \\
\text { coeficients }\end{array}$ & $\begin{array}{c}\text { Standard } \\
\text { error }\end{array}$ & $\mathrm{t}$ & $\mathrm{P}$ \\
\hline Mean/Intercept & 1.923455 & 0.054159 & 35.51516 & 0.00000 \\
$\mathrm{X}$ (linear) & 1.298451 & 0.127013 & 10.22294 & 0.00007 \\
$\mathrm{Y}$ (linear) & 0.53881 & 0.127013 & 4.24260 & 0.002829 \\
\hline
\end{tabular}

$\mathrm{X}$ - Concentration of $\mathrm{NaOH}$ (codified); $\mathrm{Y}$ - Time of immersion (codified). which chlorophyll is concentrated, besides tannin, responsible for the astringent and bitter flavor. On trial (1) with $3.41 \mathrm{~g} . \mathrm{L}^{-1}$ and 2.45 minutes, the greenish color was also present and the removal of the incrustations of the pericarp did not occur showing that in those experimental conditions the peeling was not effective. On trials (4) with 8.25 g.L. $\mathrm{L}^{-1}$ and 8.00 minutes, (6) with 13.40 g.L. $\mathrm{L}^{-1}$ and 2.45 minutes, (7) with 13.04 g.L. $\mathrm{L}^{-1}$ and 7.05 minutes, and (11) with 15.00 g. $\mathrm{L}^{-1}$ and 4.75 minutes a considerable corrosion of the external mesocarp occurred $(13,17 \%)$ lowering the efficiency of the chemical peeling process and consequent reduction on flour output. Trials (5), (8), and (9), each with 8.25 g.L. ${ }^{-1}$ and 4.75 minutes (replicates in the central point) achieved an efficient removal of the epicarp. In order to reduce the amount of $\mathrm{NaOH}$ in the solution, the time of immersion was increased along the 20.0 area of converted mass loss (Figure 1), equivalent to a percentage of mass loss of $11.70 \%$. There was a displacement for the combination of $5.80 \mathrm{~g} . \mathrm{L}^{-1}$ and 7.05 minutes, which was defined as the ideal binomial of $\mathrm{NaOH}$ concentration and time of immersion for an adequate chemical peeling of pequi fruit.

Garrote et al. (1993) got a mass loss of $20.00 \%$ in the potato peeling with $12.72 \%$ sodium hydroxide solution, at $95^{\circ} \mathrm{C}$ and 5.67 minutes. According to Cruess (1973), the usual concentration of the lixiviating solution for fruits can vary from 1.50 to $2.00 \%$ of $\mathrm{NaOH}$, but it may be higher for green fruits or lower for ripe fruits. For carrots and potatoes, it usually varies from 10.00 to $15.00 \%$ according to the species and ripening stage. For fruits in general, the time of immersion varies from 0.50 to 2.00 minutes, but for sweet potatoes it varies from 6.00 to 8.00 minutes, due to harder epidermis. However, the resistance of pequi epidermis is more similar to roots and tubers.

The centesimal composition of external mesocarp pequi flour as well as the standard deviation and coefficients of variation are shown on Table 5.

The per cent compositions obtained in this study were similar to those obtained by Barbosa and Amante (2007) which elaborated pequi shell flour using epicap and external mesocarp with average contents of proteins of $5.77,50.94 \mathrm{~g} .100 \mathrm{~g}^{-1}$ of carbohydrates and 39.97 g. $100 \mathrm{~g}^{-1}$ of total dietary fibers. However, those authors obtained ashes and lipid contents of 1.78 and 1.54 g. $100 \mathrm{~g} \mathrm{~g}^{-1}$ which were lower and higher than those obtained in this study. All plant parts are covered by the cuticle: an external layer with a structure essentially composed of lipids deposited in layers. Due to such structure, the chemical removal of the epicarp could lead to a reduction of lipids and tannins in the external mesocarp pequi flour.

According to the Brazilian Table of Food Composition of USP (UNIVERSIDADE..., 2007), wheat flour has the following composition in percentage: moisture content $10.52 \mathrm{~g}$; dietary fiber $2.82 \mathrm{~g}$, ashes $0.51 \mathrm{~g}$, proteins $11.66 \mathrm{~g}$, lipids $1.35 \mathrm{~g}$, and carbohydrates $75.00 \mathrm{~g}$. Aiming at replacing wheat flour with "pequi" external mesocarp flour in bread making products, when it is compared wheat flour with external mesocarp pequi flour, it is noticed that in the external mesocarp pequi flour the dietary fiber contents and ashes were higher than those in wheat flour: 1.24 and $461.00 \%$, respectively. Nevertheless, moisture content, carbohydrates, protein, and lipid contents were lower 

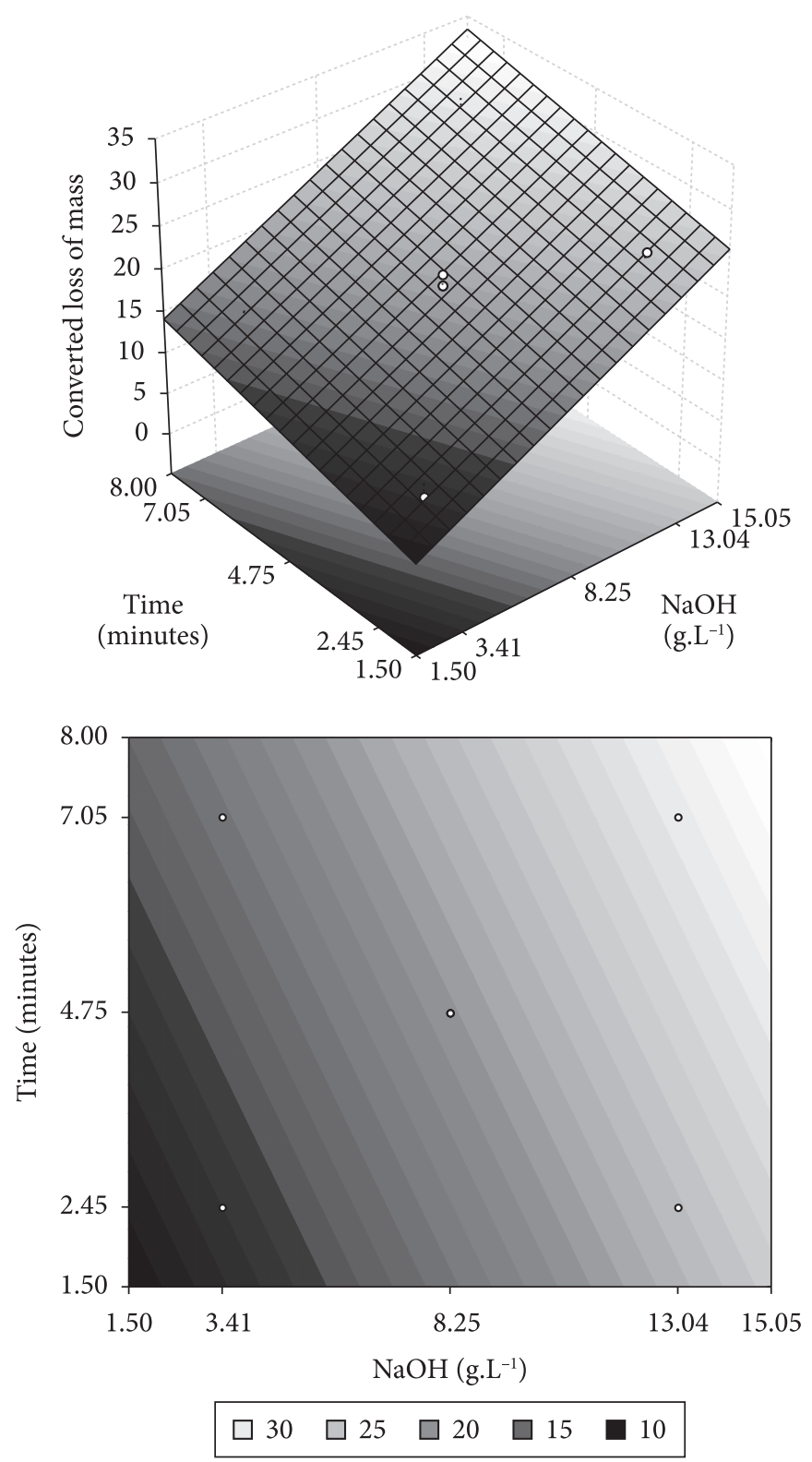

Figure 1. Curves of surface response and regression equation of the converted mass loss $(W=\arcsin \sqrt{Z / 100})$ during the chemical peeling as a function of $\mathrm{NaOH}\left(\mathrm{g} . \mathrm{L}^{-1}\right)$ concentration $(\mathrm{X})$ and time of immersion (minutes) (Y).

in the external mesocarp pequi flour (242.00, 51.00 and $109.00 \%$ respectively). Carbohydrates, lipids, and protein contents are usually higher in cereals, but fruits are richer in mineral and vitamins. A great improvement associated with this nutritional profile is the high dietary fiber content present in the external mesocarp pequi flour, corresponding to approximately 12.5 -fold the total dietary fiber content of wheat flour.

Dietary fiber components perform important physiological roles in the intestine and in controlling and/or preventing certain chronicle degenerative illnesses. It is believed that fibers act in the gastro intestinal functions through physical activities and hydration capability, besides increasing the volume and
Table 5. Mean values of percent composition, caloric value, and contents of some minerals of pequi flour (PFF) with their Standard deviation and coefficient of variation.

\begin{tabular}{lc}
\hline Characteristics & $\begin{array}{c}\text { Mean } \pm \text { standard deviation } \\
\text { (Coefficient of variation) }\end{array}$ \\
\hline Moisture content $^{\mathrm{a}}$ & $3.08 \pm 0.05(1.46)$ \\
Ashes $^{\mathrm{a}}$ & $2.86 \pm 0.04(1.36)$ \\
Proteínas $^{\mathrm{a}}$ & $5.59 \pm 0.06(1.03)$ \\
Lipíds $^{\mathrm{a}}$ & $0.85 \pm 0.04(4.55)$ \\
Carbohydrates $^{\mathrm{a}}$ & $49.59 \pm 0.23(0.45)$ \\
Dietary fiber $^{\mathrm{a}}$ & $38.02 \pm 0.21(0.53)$ \\
Cálcium $^{\mathrm{b}}$ & $181.78 \pm 0.02(0.01)$ \\
Magneseum $^{\mathrm{b}}$ & $534.03 \pm 0.50(0.09)$ \\
Manganese $^{\mathrm{b}}$ & $14.81 \pm 0.02(0.13)$ \\
Copper $^{\mathrm{b}}$ & $1.03 \pm 0.01(0.97)$ \\
Iron $^{\mathrm{b}}$ & $2.97 \pm 0.01(0.01)$ \\
Zinc $^{\mathrm{b}}$ & $0.00 \pm 0.00(0.00)$ \\
\hline${ }^{\mathrm{a}} \mathrm{g} .100 \mathrm{~g}^{-1}$; ${ }^{\mathrm{b}} \mathrm{mg}^{100 \mathrm{~g}^{-1}}$ &
\end{tabular}

speed of food and feces in the intestinal tract. Dietary fibers also have the capability to act in combination with other components of the diet through other mechanisms with the capability of dragging those components in larger amounts in fecal excretion (RAUPP; SGARBIERI, 1996). Taking into account the fiber contents of $38.02 \mathrm{~g} .100 \mathrm{~g}^{-1}$, the external mesocarp pequi flour can be classified as a high fiber content food.

Wheat flour has $21.00 \mathrm{mg} .100 \mathrm{~g}^{-1}$ of calcium, $37.00 \mathrm{mg} .100 \mathrm{~g} \mathrm{~g}^{-1}$ of magnesium, $0.87 \mathrm{mg} .100 \mathrm{~g}^{-1}$ of manganese, $0.23 \mathrm{mg} .100 \mathrm{~g}^{-1}$ of copper, $4.46 \mathrm{mg} .100 \mathrm{~g} \mathrm{~g}^{-1}$ of iron, and $1.12 \mathrm{mg} .100 \mathrm{~g} \mathrm{~g}^{-1}$ of zinc (UNIVERSIDADE..., 2007). By comparing wheat flour with external mesocarp pequi flour, it can be observed that external mesocarp pequi flour has higher contents of calcium (793.00\%), magnesium (1.39\%), manganese (1.66\%), and copper (345.00\%); but less iron (31.00\%) and zinc was not detected. According to the Dietary Reference Intakes (PADOVAN et al., 2006), the adequate daily ingestion for men and women is: calcium from 1000.00 to $1200.00 \mathrm{mg}$; magnesium from 320.00 to $420.00 \mathrm{mg}$; manganese from 1.80 to $2.30 \mathrm{mg}$, and copper $0.90 \mathrm{mg} .100 \mathrm{~g}^{-1}$ of external mesocarp pequi flour contributes with 15.15 to $18.19 \%$ of calcium, 127.15 to $166.89 \%$ of magnesium, 643.89 to $822.74 \%$ of manganese, and $110.92 \%$ of copper.

\section{Conclusions}

Due to the uneven dimensions of fruits, the chemical epicarp removal proved a viable alternative for the development of the "pequi" external mesocarp flour.

The best combination for an efficient removal of the pericarp of pequi with the lowest mass loss is 7.05 minutes immersion in a 5.8 g. $\mathrm{L}^{-1}$ of $\mathrm{NaOH}$ solution.

The external mesocarp pequi flour is rich in total dietary fiber, total carbohydrates, ashes, magnesium, calcium, manganese, and copper, but it is poor in lipids, zinc, and iron.

Further research is necessary to better characterize the external mesocarp pequi flour in terms of quality of phenolic 
substances, among them the tannins, as well as to detect the inhibitors and antinutrient agents and verify the performance of of the flour in the acceptability tests as an ingredient in the formulation of food.

\section{Acknowledgements}

The authors are grateful to $\mathrm{CNPq}$ - Conselho Nacional de Pesquisa (National Research Council) for the financial support granted to an undergraduate member of our research team.

\section{References}

ALESON-CARBONELL, L. et al. Quality characteristics of a nonfermented dry-cured sausage formulated with lemon albedo. Journal of the Science and Food Agriculture, v. 84, p. 2077-2084, 2004.

ASSOCIATION OF OFFICIAL ANALYTICAL CHEMISTS - AOAC INTERNATIONAL. Official methods of analysis of AOAC International. 3. ed. Maryland: AOAC International, 1997.

BARBOSA, R. C. M. V.; AMANTE, E. R. Farinha da Casca de Pequi (Caryocar brasiliense). In: CONGRESSO BRASILEIRO DE FRUTICULTURA, 17., 2007, Florianópolis. Anais... Florianópolis: Sociedade Brasileira de Fruticultura, 2007. CD-ROM.

CHUNG, K. T. et al. Tannins and human health: a review. Critical Reviews in Food Science and Nutritition, v. 38, n. 6, p. 421-464, 1998.

CRUESS, W. V. Produtos industriais de frutas e hortaliças. São Paulo: Usaid, 1973. $444 \mathrm{p}$.

DE VRIES, J. M. Dietary fiber: the influence of definition on analysis and regulation. Journal of AOAC International, v. 87, p. 682-706, 2004.

EASTWOOD, M. Dietary fiber: how did we get where are? Annual Review of Nutrition, v. 25, p. 1-8, 2005.

FERREIRA, M. B. Frutos comestíveis nativos do Cerrado em Minas Gerais. Informe Agropecuário, v. 6, p. 9-18, 1980.

GARCÍA, M. L.; CÁCERES, E.; SELGAS, M. D. Utilization of fruits fibers in conventional and reduced-fat cooked-meat sausages. Journal of the Science and Food Agriculture, v. 87, p. 624-631, 2007.

GARROTE, R. L. et al. Optimizing processing condictions for chemical peeling of potatos using response surface methodology. Journal of Food Science, v. 58, p. 821-926, 1993.

INSTITUTE OF MEDICINE. Dietary reference intakes: proposed definition of dietary fiber. Washington: National Academy, 2001. $74 \mathrm{p}$.
KLINK, C. A.; MACHADO, R. D. A conservação do Cerrado brasileiro. Megadiversidade, v. 1, p. 147-155, 2005.

PADOVAN, R. M. et al. Dietary reference intakes: application of tables in nutricional studies. Revista Nutrição, v. 19, p. 741-760, 2006.

PHILLIPS, G. O.; OGASAWARA, T.; USHIDA, K. The regulatory and scientific approach to defining gum Arabic (Acacia senegal and Acacia seyal) as a dietary fibres. Food Hydrocolloids, v. 22, p. 24-35, 2008.

RAUPP, D. S.; SGARBIERI, V. C. Efeitos de frações fibrosas extraídas de feijão (Phaseolus vulgaris, L.) na utilização de macro e micronutrientes da dieta pelo rato. Ciência e Tecnologia de Alimentos, v. 16, p. 100-107, 1996.

ROESLER, R. et al. Atividade antioxidante de frutas do Cerrado. Ciência e Tecnologia de Alimentos, v. 27, p. 53-60, 2007.

SANTOS BUEGA, G.; SACALBERT, A. Proanthocyanidins and tanninlike compounds - nature, occurrence, dietary intake and effects on nutrition and health. Journal of the Food Science and Agriculture, v. 80 , p. 1094-1117, 2000.

SILVA, J. A. et al. Frutas nativas dos cerrados. Planaltina: Embrapa/ CPAC, 1994. $166 \mathrm{p}$.

SILVA, R. S.; CHAVES, L. J.; NAVES, R. V. Caracterização de frutos e árvores de cagaita (Eugenia dysenterica D.C.) no sudeste do Estado de Goiás, Brasil. Revista Brasileira de Fruticultura, v. 23, p. 330-334, 2001.

STATISTICA for Windows-Release 5.0. Tulsa, USA: StatSoft, 1995.

STEEL, R. G. D.; TORRIE, J. H. Principles and procedures of statistics. 2. ed. New York: McGraw-Hill Book Company, 1980. p. 233.

UNIVERSIDADE DE SÃO PAULO - USP. Tabela Brasileira de Composição de Alimentos. Available from: <http://www.fcf.usp. br/tabela>. Access in: 23 Aug. 2007.

VERA, R. et al. Caracterização física dos frutos do pequizeiro (Caryocar brasiliense Camb.) no estado de Goiás. Pesquisa Agropecuária Tropical, v. 35, p. 71-79, 2005.

VERA, R. et al. Caracterização física e química de frutos do pequizeiro (Caryocar Brasiliense Camb.) oriundos de duas Regiões do Estado de Goiás, Brasil. Pesquisa Agropecuária Tropical, v. 37, p. 93-99, 2007.

WAGHORN, G. C.; McNABB, W. C. Consequences of plant phenolic compounds for productivity and health of ruminants. Proceedings of Nutritional Society, v. 62, p. 383-392, 2003.

WALTER, R. H. et al. Edible fibers from apple pomace. Journal of Food Science, v. 50, p. 747-749, 1985. 